\title{
PENGARUH PARIWISATA TERHADAP PERTUMBUHAN EKONOMI DI INDONESIA
}

\author{
Anggita Permata Yakup, Tri Haryanto \\ Faculty of Economics and Business, Airlangga University
}

\begin{abstract}
The tourism sector has an important role as one of the sources of foreign exchange earnings and can encourage national economic growth. This study examines the effect of tourism on economic growth in Indonesia based on time series data during the years of 1975 - 2017. This study uses a simultaneous equation model estimated by Two Stage Least Square. The results show that tourism has a positive effect on economic growth and conversely economic growth has a positive effect on tourism. Another factor that influences the demand for tourism in Indonesia is the exchange rate and inflation.
\end{abstract}

Keywords: Tourism; Economic Growth; Two Stage Least Square; Indonesia

\begin{abstract}
ABSTRAK
Sektor pariwisata memiliki peranan penting sebagai salah satu sumber penerimaan devisa serta dapat mendorong pertumbuhan ekonomi nasional. Penelitian ini mengkaji pengaruh pariwisata terhadap pertumbuhan ekonomi di Indonesia berdasarkan data time series selama tahun 1975 - 2017. Penelitian ini menggunakan model persamaan simultan yang diestimasi dengan Two Stage Least Square. Hasil menunjukkan bahwa pariwisata berpengaruh positif terhadap pertumbuhan ekonomi dan sebaliknya pertumbuhan ekonomi berpengaruh positif terhadap periwisata. Faktor lain yang berpengaruh terhadap permintaan pariwisata di Indonesia yaitu nilai tukar dan inflasi.
\end{abstract}

Kata kunci: Pariwisata; Pertumbuhan Ekonomi; Two Stage Least Square; Indonesia

\section{PENDAHULUAN}

Sektor pariwisata menjadi komponen kunci perekonomian di sektor jasa yang mampu memicu pertumbuhan ekonomi negara-negara di dunia. Beberapa ahli mengatakan bahwa sektor pariwisata merupakan sektor yang kompleks dan fragmented, yang keberadaannya sulit untuk diukur dan didefinisikan sebagaimana tren pariwisata yang terus berubah setiap waktunya. Sektor pariwisata telah berkontribusi dalam pembangunan perekonomian dunia dan menggerakan hampir 700 juta orang di seluruh dunia. Pariwisata diharapkan menjadi sektor yang terus berkembang sebagimana orang-orang saat ini yang menjadi semakin mobile dan sejahtera (Kusni, Kadir, \& Nayan, 2013).

Kegiatan pariwisata yang dilakukan wisatawan mancanegara, yaitu datang untuk mengonsumsi komoditas wisata di negara tujuan wisata. Pada neraca nasional, pengeluaran wisatawan ini dipandang sebagai invisible export perekonomian negara destinasi. Pengeluaran tersebut dapat dianggap sebagai stimulus bagi konsumsi, yang diperoleh dari wisatawan mancanegara yang berkunjung (Eugenio-Martin, Scarpa, \& Morales, 2004). Hal ini berarti terjadi peningkatan produksi dan pendapatan, dimana keduanya akan meningkatkan pertumbuhan ekonomi. Di lain pihak, pertumbuhan ekonomi yang merupakan akumulasi produksi dan belanja dari output barang dan jasa, akan dapat mendorong perkembangan pariwisata. 
Perkembangan pariwisata juga mendorong dan mempercepat pertumbuhan ekonomi. Pariwisata menciptakan permintaan, baik konsumsi maupun investasi, dimana keduanya akan menimbulkan kegiatan produksi barang dan jasa. Selama berwisata, wisatawan akan melakukan perbelanjaan, sehingga secara langsung menimbulkan permintaan pasar barang dan jasa (tourism final demand). Selanjutnya, tourism final demand secara tidak langsung menimbulkan permintaan akan barang modal dan bahan baku (investment derived demand), untuk beroperasi memenuhi permintaan wisatawan akan barang dan jasa tersebut. Dalam usaha memenuhi permintaan pariwisata, diperlukan investasi di bidang transportasi dan komunikasi, perhotelan dan akomodasi lain, industri kerajinan, industri produk konsumen, industri jasa, rumah makan, dan lain sebagainya (Belloumi, 2010; Durbarry \& Sinclair, 2003; Lise \& Tol, 2000; Samimi, Sadeghi, \& Sadeghi, 2011).

Pariwisata berpengaruh terhadap pertumbuhan ekonomi melalui beberapa jalur (Brida \& Pulina, 2010). Pertama, sektor pariwisata sebagai penghasil devisa untuk memperoleh barang modal yang digunakan dalam proses produksi. Kedua, pengembangan pariwisata menstimulus investasi di bidang infrakstruktur (Sakai, 2006). Ketiga, pengembangan sektor pariwisata mendorong pengembangan sektor-sektor ekonomi lainnya malalui direct, indirect, dan induced effect (Spurr, 2006). Keempat, pariwisata ikut berkontribusi dalam kesempatan kerja dan peningkatan pendapatan (Lee \& Chang, 2008). Kelima, pariwisata menyebabkan positive economies of scale (Weng \& Wang, 2004). Pariwisata juga merupakan faktor penting dalam penyebaran technical knowledge, mendorong research and development, dan akumulasi modal manusia (Blake, Sinclair, \& Soria, 2006).

Berdasarkan World Travel and Tourism Council (2015) kontribusi pariwisata Indonesia terhadap PDB pada tahun 2014 adalah Rp325.467 miliar (3,2\% dari PDB). Ini diperkirakan akan naik 6,0\% menjadi Rp345.102 miliar pada tahun 2015. Pariwisata Indonesia juga berkontribusi terhadap tenaga kerja pada tahun 2014 sebanyak 3.326.000 tenaga kerja (2,9\% dari total tenaga kerja). Ini diperkirakan akan meningkat sebesar 2,3\% pada tahun 2015 dan naik sebesar 1,4\% per tahun menjadi 3.905.000 tenaga kerja (2,9\% dari total tenaga kerja) pada tahun 2025. Selain itu, pariwisata Indonesia berkontribusi terhadap Visitor Exports dengan menghasilkan Rp132.159 miliar (5,6\% dari total ekspor) pada 2014. Ini diperkirakan akan tumbuh sebesar 5,5\% pada 2015 dan tumbuh sebesar 5,5\% per tahun dari tahun 2015 - 2025, menjadi Rp238.606 miliar pada tahun 2025 (6,5\% dari total ekspor). Pariwisata Indonesia juga mendatangkan investasi, pada tahun 2014. Investasi yang telah dilakukan adalah Rp167.435 miliar (5,3\% dari total investasi) dan naik 5,7\% pada 2015, kemudian naik lagi sebesar 7,1\% per tahun selama sepuluh tahun ke depan menjadi Rp352.910 miliar pada tahun 2025 (6,0\% dari total investasi). Hal ini mencerminkan aktivitas ekonomi dihasilkan oleh industri seperti hotel, agen perjalanan, maskapai penerbangan, dan layanan transportasi penumpang lainnya (tidak termasuk layanan komuter). Hal itu juga memberikan dukungan secara langsung untuk kegiatan-kegiatan industri restoran dan hiburan.

Berdasarkan Badan Pusat Statistik (2018), jumlah kunjungan wisatawan di Indonesia dari tahun ke tahun semakin meningkat, yaitu tumbuh sekitar 13,2\% pada tahun 2008 dan meningkat sekitar 1,4\% pada tahun 2009. Pada tahun 2015, jumlah kunjungan wisatawan meningkat sebesar $7,2 \%$, tumbuh di atas rata-rata negara lain yang hanya 4,4\%. Pada tahun 2017, kunjungan wisatawan mancanegara ke Indonesia tumbuh menjadi 14,3 juta kunjungan, dimana keberhasilan ini merupakan dedikasi, komitmen, strategi, dan teori pengembangan sektor pariwisata yang dijalankan. Akan tetapi, keberhasilan ini tidak diikuti dengan peningkatan pertumbuhan ekonomi di Indonesia pada tahun 2017 yang tumbuh sebesar 5,07\%. Meskipun pertumbuhan ekonomi di 
Indonesia mengalami perbaikan peningkatan dari tahun ke tahun, tetapi peningkatan pertumbuhan pariwisata masih lebih tinggi peningkatan pertumbuhan ekonomi.

Oleh karena itu, perlu dilakukan analisis mengenai faktor-faktor yang menentukan perkembangan wisatawan dalam perspektif makroekonomi. Analisis ini dapat dilakukan dengan menggunakan salah satu indikator pariwisata, yaitu International Tourism Arrivals sebagai variabel terikat. Untuk variabel bebas yang digunakan, antara lain GDP per kapita sebagai proksi dari pertumbuhan ekonomi, nilai tukar rupiah, dan indeks harga konsumen.

Nilai tukar sangat penting dalam memengaruhi keputusan wisatawan mancanegara dalam melakukan wisata, terutama kurs antara mata uang negara asal turis tersebut dengan mata uang negara tujuan destinasi. Semakin banyak informasi biaya perjalanan antar tujuan destinasi wisata, maka wisatawan semakin sensitif terhadap harga yang diukur dengan nilai tukar, sehingga wisatawan akan bergeser dari negara dengan nilai tukar yang tinggi (depresiasi) ke negara dengan nilai tukar rendah (apresiasi). Oleh karena itu, nilai tukar merupakan faktor penentu yang esensial bagi pariwisata (Patsouratis, Frangouli, \& Anastasopoulos, 2005).

Menurut (Chiu \& Yeh, 2017), hubungan pariwisata dan pertumbuhan ekonomi telah dianalisis dengan pendekatan hipotesis TLG (Tourism Led-Growth), ketika kondisi pariwisata berubah dengan menggunakan tiga spesialisasi pariwisata, yaitu (1) rasio penerimaan pariwisata internasional terhadap PDB; (2) rasio jumlah kedatangan wisatawan internasional dengan jumlah keberangkatan wisatawan internasional (rasio wisatawan); dan (3) rasio layanan perjalanan ekspor layanan komersial dengan layanan perjalanan impor layanan komersial (rasio layanan perjalanan). Tingkat spesialisasi pariwisata yang lebih tinggi, memiliki arti negara-negara menunjukkan lebih banyak melakukan pengembangan di bidang pariwisata.

Pariwisata telah menarik perhatian dalam literatur tentang perkembangan ekonomi. Dorongan utama dalam banyak penelitian, yaitu tentang dampak ekonomi pariwisata untuk mengukur dampak langsung dan tidak langsung terhadap ekonomi (Pearce \& Butler, 2010). Seperti yang ditunjukkan dalam Mangion, Durbarry, \& Sinclair (2005), sebagian besar studi tentang pariwisata yang diteliti selama paruh kedua abad ke-20, tidak secara tegas diarahkan pada topik peran pariwisata dalam pembangunan ekonomi. Di dalam berbagai studi, dianggap bahwa pendapatan devisa dari pariwisata dapat digunakan untuk mengimpor barang modal untuk menghasilkan barang dan jasa, pariwisata dapat mendukung pekerjaan atau pendapatan pajak tambahan (Durrbary, 2002), dan pariwisata dapat menghasilkan pertumbuhan ekonomi dengan meningkatkan efisiensi melalui kompetisi. Pariwisata juga dapat memfasilitasi eksploitasi skala ekonomi di tingkat lokal.

Pengembangan pariwisata telah menjadi fokus banyak penelitian baru-baru ini dalam literatur, karena industri ini tidak hanya meningkatkan pendapatan devisa, tetapi juga menciptakan peluang kerja bagi negara-negara tujuan pariwisata, sehingga memacu pertumbuhan ekonomi. Namun, pariwisata adalah industri padat karya dengan produktivitas rendah dan pengembangan pariwisata dapat mendorong beralihnya sumber daya dari industri produktif tinggi (manufaktur) ke sektor pariwisata, yang mengakibatkan penurunan dalam output manufaktur (Nowak, Sahli, \& Sgro, 2003). Penelitian Hazari, Nowak, Sahli, \& Zdravevski (2003) menunjukkan bahwa ledakan wisata di daerah perkotaan dapat memiskinkan daerah di pedesaan, yang berarti pertumbuhan pariwisata dapat membahayakan pertumbuhan ekonomi. Dengan demikian, upaya mempromosikan pengembangan pariwisata dapat meningkatkan atau merusak pertumbuhan ekonomi, tergantung pada situasinya. 
Berdasarkan beberapa argumen di atas, maka penelitian ini bertujuan untuk menganalisis pengaruh pariwisata terhadap pertumbuhan ekonomi di Indonesia. Penelitian ini diharapkan dapat menjadi referensi bagi pemerintah, peneliti lainnya, serta bagi masyarakat dalam mengembangkan kepariwisataannya. Hal ini karena pariwisata memiliki peranan penting sebagai salah satu sumber bagi penerimaan devisa, serta dapat mendorong pertumbuhan ekonomi nasional.

\section{METODE PENELITIAN}

Penelitian ini menggunakan data time series periode 1975 - 2017. Data di peroleh dari berbagai sumber, diantaranya adalah BPS Indonesia (2018), Bank Indonesia (2018), IMF (2018), dan World Bank (2018).

Model analisis menggunakan model persamaan simultan. Spesifikasi model adalah seperti berikut:

$$
\begin{aligned}
& T A_{t}=\alpha_{0}+\alpha_{1} E G_{t}+\alpha_{2} E R_{t}+\alpha_{3} C P I_{t}+\varepsilon_{t} \\
& E G_{t}=\alpha_{0}+\alpha_{1} \widehat{T A}_{t}+\alpha_{2} E M P_{t}+\alpha_{3} G F C F_{t}+\alpha_{4} L E B_{t}+\alpha_{5} S_{\text {School_enroll }}+\mu_{t}
\end{aligned}
$$

keterangan:

$\mathrm{TA}$

= Jumlah kunjungan wisatawan mancanegara (dalam Logarimat Natural)

$\widehat{T A}_{t} \quad=$ Jumlah kunjungan wisatawan mancanegara (estimated)

EG = Pertumbuhan Ekonomi (dalam Logarimat Natural)

ER = Nilai Tukar Rupiah (dalam Logarimat Natural)

CPI = Indeks harga konsumen (dalam Logarimat Natural)

LEB = Umur Harapan Hidup (dalam Logarimat Natural)

EMP = Angkatan kerja (dalam Logarimat Natural)

GFCF = Penanaman modal tetap bruto (dalam Logarimat Natural)

School_enroll = School enrollment, primary (dalam Logarimat Natural)

$\varepsilon, \mu \quad=$ Error term

$t \quad=$ Time series

Estimasi parameter menggunakan metode Two Stages Least Square.

\section{HASIL DAN PEMBAHASAN}

Rata-rata jumlah kunjungan wisatawan mancanegara pada penelitian ini sebanyak 4.177.353 orang per tahun. Jumlah kunjungan wisatawan mancanegara terendah adalah 366.293 
orang per tahun dan tertinggi sebanyak 14.039 .799 orang per tahun. Salah satu faktor yang menyebabkan tinggi rendahnya jumlah kunjungan wisatawan mancanegara adalah nilai tukar dan indeks harga konsumen. Pada penelitian ini, nilai tukar terendah sebesar Rp415 per USD dan tertinggi sebesar Rp13.389 per USD.

Selain itu, terdapat variabel pertumbuhan ekonomi. Persentase rata-rata pertumbuhan ekonomi pada penelitian ini adalah 5,36\%, pertumbuhan ekonomi terendah adalah $-13,13 \%$, dan pertumbuhan ekonomi tertinggi adalah 9,88\%. Faktor lain yang memengaruhi pertumbuhan ekonomi adalah tenaga kerja, gross fixed capital formation, umur harapan hidup, dan tingkat sekolah.

Tabel 1. Statistik Deskriptif

\begin{tabular}{|l|c|c|c|c|}
\hline \multicolumn{1}{|c|}{ Variabel } & Mean & SD & Max & Min \\
\hline Kedatangan wisatawan (Juta orang) & 4.177 .353 & $3.377 .363,143$ & 14.039 .799 & 366.293 \\
\hline Pertumbuhan ekonomi (\%) & 5,36209 & 3,35792 & 9,88 & $-13,13$ \\
\hline Nilai tukar (Rp/\$) & 5.404 & $4.564,08$ & 13.389 & 415 \\
\hline CPI & 45,8658 & 44,7974 & 142 & 3 \\
\hline Angkatan kerja yang bekerja (\%) & 2,57818 & 0,68987 & 1,28200 & 3,598 \\
\hline Umur harapan Hidup (Usia) & 65 & 3,57759 & 69 & 57 \\
\hline GFCF (\%) & 5,33394 & 0,24575 & 5,75702 & 4,89608 \\
\hline Tingkat Pendidikan (\%) & 2,03756 & 0,02957 & 2,08349 & 1,94020 \\
\hline
\end{tabular}

Sumber : Hasil Perhitungan Penulis, 2019

Hasil estimasi Two Stages Least Square untuk tahap 1 dijelaskan pada tabel 2 bahwa variabel independen secara simultan atau bersama-sama berpengaruh terhadap Tourist Arrivals pada $\alpha=$ $1 \%$. Pertumbuhan ekonomi, niai tukar rupiah, dan indeks harga konsumen dengan tingkat signifikansi $1 \%$.

Tabel 2. Hasil Estimasi Two Stage Least Square

\begin{tabular}{|c|c|c|c|}
\hline \multicolumn{2}{|c|}{ Tahap $1^{\text {a) }}$} & \multicolumn{2}{|c|}{ Tahap 2 b) } \\
\hline Variabel & Koefisen & Variabel & Koefisien \\
\hline \multirow{2}{*}{$\begin{array}{l}\text { Pertumbuhan } \\
\text { Ekonomi }\end{array}$} & $3,32898^{* * *}$ & \multirow{2}{*}{ Tourist Arrivals } & $0,1204111^{* * *}$ \\
\hline & $(0,294574)$ & & $(0,0340355)$ \\
\hline \multirow{2}{*}{ Nilai Tukar } & $-0,933616^{* * *}$ & \multirow{2}{*}{$\begin{array}{l}\text { Angkatan Kerja yang } \\
\text { Bekerja }\end{array}$} & $0,0515225^{* *}$ \\
\hline & $(0,116231)$ & & $(0,0184761)$ \\
\hline \multirow{6}{*}{$\begin{array}{l}\text { Indeks Harga } \\
\text { Konsumen }\end{array}$} & $-1,122022^{* * *}$ & \multirow{2}{*}{$\begin{array}{l}\text { Gross Fixed } \\
\text { Capital Formation }\end{array}$} & $0,1623896^{* * *}$ \\
\hline & $(0,176981)$ & & $(0,00864)$ \\
\hline & & \multirow{2}{*}{ Umur Harapan Hidup } & $1,619996^{* *}$ \\
\hline & & & $(0,7435277)$ \\
\hline & & \multirow{2}{*}{$\begin{array}{l}\text { School Enrollment, } \\
\text { Primary }\end{array}$} & $0,0689784^{*}$ \\
\hline & & & $(0,0965708)$ \\
\hline \multirow{2}{*}{ Konstanta } & 4,479497 & \multirow{2}{*}{ Konstanta } & 4,483935 \\
\hline & $(4,890564)$ & & $(2,194778)$ \\
\hline$R$-square & 0,9780 & $R$-square & 0,9985 \\
\hline Prob $>F$ & 0,0000 & Prob $>F$ & 0,0000 \\
\hline
\end{tabular}

a) Variabel dependen : Kedatangan wisatawan mancanegara

b) Variabel dependen : Pertumbuhan ekonomi

- Angka dalam kurung () : Standart Error

*signifikansi pada $\alpha$ (level of significance) : 10\%

${ }^{* *}$ signifikansi pada $\alpha$ (level of significance) : $5 \%$ 
${ }^{* * *}$ signifikansi pada $\alpha$ (level of significance) : $1 \%$

Sumber: Hasil Perhitungan Penulis, 2019

Hasil tahap 1 menunjukkan peningkatan jumlah kunjungan wisatawan mancanegara dapat meningkatkan pertumbuhan ekonomi. Apabila pertumbuhan ekonomi naik sebesar 1\%, maka jumlah kunjungan wisatawan mancanegara akan meningkat sebesar 3,32898\%. Menurut (Proença \& Soukiazis, 2005), pertumbuhan ekonomi merupakan faktor terpenting yang memengaruhi keputusan calon wisatawan mancanegara untuk berwisata. Pertumbuhan ekonomi yang tinggi akan meningkatkan total jumlah kunjungan wisatawan mancanegara. Peningkatan pertumbuhan ekonomi di negara asal wisatawan akan memberikan keuntungan bagi industri pariwisata di negara tujuan wisata. Hal ini dapat diartikan bahwa pertumbuhan ekonomi negara asal wisatawan berhubungan positif terhadap jumlah kunjungan wisatawan.

Nilai tukar rupiah memiliki korelasi negatif terhadap kunjungan wisatwan mancanegara. Semakin naik nilai tukar apresiasi sebesar 1\%, maka menyebabkan jumlah kunjungan wisatawan mancanegara menurun sebesar 0,933616\%. Menurut (Utami, Hartono, \& Awirya, 2016), ketika mata uang negara tujuan mengalami apresiasi, nilai tukar mata uang negara asal wisatawan mancanegara terhadap negara tujuan akan melemah, sehingga harga akan meningkat. Hal tersebut akan berakibat pada menurunnya daya beli wisatawan dan mengurangi jumlah kunjungan wisatawan mancanegara.

Indeks Harga Konsumen (IHK) berpengaruh negatif terhadap jumlah kunjungan wisatawan mancanegara. Semakin naik tingkat indeks harga konsumen sebesar 1\%, maka jumlah kunjungan wisatawan mancanegara menurun sebesar 1,122022\% . Menurut (Choyakh, 2009), indeks harga konsumen dipandang sebagai harga pariwisata negara tujuan. Penggunaan nilai IHK secara tidak langsung juga telah memasukan pengaruh dari inflasi. Jika suatu negara mengalami inflasi, maka akan terjadi kenaikan harga pada barang dan jasa secara umum, sehingga meningkatkan IHK. Kenaikan IHK tersebut akan meningkatkan harga relatif terhadap negara asal wisatawan mancanegara, sehingga akan menurunkan jumlah kunjungan wisatawan mancanegara.

Hasil estimasi Two Stages Least Square untuk tahap 2 dijelaskan pada tabel 2, bahwa variabel independen yang bersifat endogen secara simultan atau bersama-sama berpengaruh terhadap pertumbuhan ekonomi pada $\alpha=1 \%$. Kunjungan wisatawan mancanegara dan gross fixed capital formation dengan tingkat signifikansi $1 \%$, tenaga kerja dan umur harapan hidup dengan tingkat signifikansi 5\%, sedangkan variabel tingkat sekolah dengan tingkat signifikansi 10\%.

Hasil penelitian menunjukkan bahwa pertumbuhan ekonomi dapat meningkatkan jumlah kunjungan wisatawan mancanegara. Apabila jumlah kunjungan wisatawan mancanegara meningkat sebesar 1\%, maka pertumbuhan ekonomi meningkat sebesar 0,1204111\%. Dengan asumsi kemajuan infrakstruktur yang tinggi di bidang sektor pariwisata. Hal ini dapat terjadi hanya jika perubahan terms of trade pariwisata dengan pertumbuhan ekonomi lebih dari sekedar penyeimbangan technological gap di sektor pariwisata.

Tenaga kerja berpengaruh positif terhadap pertumbuhan ekonomi. Apabila pertumbuhan ekonomi meningkat 5\%, maka tenaga kerja akan meningkat sebesar 0,051\%. Gross Fixed Capital Formation berpengaruh positif terhadap pertumbuhan ekonomi. Apabila pertumbuhan ekonomi meningkat sebesar 1\%, maka menyebabkan Gross Fixed Capital Formation meningkat sebesar $0,162 \%$.

Umur harapan hidup memiliki korelasi positif terhadap pertumbuhan ekonomi. Apabila pertumbuhan ekonomi meningkat sebesar 5\%, maka menyebabkan umur harapan hidup 
meningkat sebesar $1,61 \%$. Tingkat sekolah berpengaruh positif terhadap pertumbuhan ekonomi. Apabila pertumbuhan ekonomi meningkat $10 \%$, maka tingkat sekolah akan naik sebesar $0,068 \%$.

Berdasarkan pembahasan hasil di atas, dapat disimpulkan bahwa industri pariwisata akan mendorong pertumbuhan ekonomi dan sebaliknya pertumbuhan ekonomi akan mendorong tumbuhnya industri pariwisata. Hal ini dilihat dari asal wisatawan berbagai mancanegara. Dalam konteks teori penawaran dan permintaan pariwisata, jumlah kunjungan wisatawan dan besarnya belanja wisatawan mancanegara termasuk dalam sisi permintaan. Besarnya peluang sektor pariwisata dalam mendorong pertumbuhan ekonomi menyebabkan banyak negara berlombalomba dalam mengembangkan kepariwisataannya, dengan meningkatkan daya saing pariwisata untuk mendatangkan devisa negara.

Hasil penelitian juga menunjukkan bahwa ada pengaruh positif dari penerimaan pariwisata terhadap pertumbuhan ekonomi, yang berarti bahwa peningkatan penerimaan pariwisata meningkatkan pertumbuhan ekonomi. Hasil ini mengonfirmasi bukti hipotesis TLG, yang menyatakan bahwa pengembangan pariwisata dapat mendatangkan pendapatan valuta asing, memacu investasi dalam infrastruktur baru, persaingan dalam industri pariwisata lokal, merangsang industri lain yang terkait dengan industri pariwisata, menyediakan lapangan kerja, mengeksploitasi skala ekonomi, pengetahuan teknis tersebar, merangsang penelitian dan pengembangan, serta mengumpulkan modal manusia (Schubert, Brida, \& Risso, 2011). Hal ini mengarah pada peningkatan pertumbuhan ekonomi.

Hasil tahap 1 dan hasil tahap 2 menunjukkan adanya hubungan antara pariwisata dan pertumbuhan ekonomi, serta bobot pariwisata terhadap ekonomi suatu negara merupakan penentu sejauh mana pariwisata mempengaruhi pertumbuhan ekonomi.

\section{SIMPULAN}

Melalui jumlah kunjungan wisatawan mancanegara, pariwisata berpengaruh positif dan signifikan terhadap pertumbuhan ekonomi dan faktor lain yang berpengaruh terhadap pariwisata, yaitu nilai tukar dan inflasi. Hal ini berarti bahwa peningkatan penerimaan pariwisata meningkatkan pertumbuhan ekonomi. Hasil tahap dua menunjukkan jumlah kunjungan wisatawan, tenaga kerja, gross fixed capital formation, umur harapan hidup, dan tingkat sekolah berpengaruh positif terhadap pertumbuhan ekonomi. Hal ini menyatakan bahwa pengembangan pariwisata dapat mendatangkan pendapatan valuta asing, memacu investasi dalam infrastruktur baru dan persaingan dalam industri pariwisata lokal, merangsang industri lain yang terkait dengan industri pariwisata, dan menyediakan lapangan kerja. Oleh karena itu, hasil analisis dari penilitian memiliki implikasi penting dalam memberikan arahan bagi pembuat kebijakan untuk mencapai jalur pertumbuhan ekonomi melalui pariwisata. Penelitian ini juga diharapkan dapat dikembangkan oleh peneliti selanjutnya dengan menambahkan beberapa variabel promosi pariwisata, akomodasi pariwisata, dan variabel yang relevan lainnya yang dapat berpengaruh terhadap pariwisata. 
46 | Bina Ekonomi

\section{DAFTAR PUSTAKA}

Badan Pusat Statistik. (2018). Diambil kembali pada tanggal 1 Agustus 2018 dari http://www.bps.go.id/

Belloumi, M. (2010). The relationship between tourism receipts, real effective exchange rate and economic growth in Tunisia. International journal of tourism research, 12(5), 550-560.

Blake, A., Sinclair, M. T., \& Soria, J. A. (2006). Tourism productivity: evidence from the United Kingdom. Annals of Tourism Research, 33(4), 1099-1120.

Brida, J. G., \& Pulina, M. (2010). Literature review on the tourism-led-growth hypothesis.

Chiu, Y. B., \& Yeh, L. T. (2017). The threshold effects of the tourism-led growth hypothesis: Evidence from a cross-sectional model. Journal of Travel Research, 56(5), 625-637.

Choyakh, H. (2009). Modelling tourism demand in Tunisia using cointegration and error correction models. In Advances in tourism economics, 71-84.

Durbarry, R., \& Sinclair, M. T. (2003). Market shares analysis: The case of French tourism demand. Annals of tourism research, 30(4), 927-941.

Durrbary, R. (2002). Long run structural tourism demand modelling: An application to France. Christel DeHaan Tourism and Travel Research Institute.

Eugenio-Martin, J. L., Scarpa, R., \& Morales, N. M. (2004). Tourism and economic growth in Latin American countries: A panel data approach. SSRN electronic journal, 1-20.

Hazari, B. R., Nowak, J. J., Sahli, M., \& Zdravevski, D. (2003). Tourism and regional immiserization. Pacific Economic Review, 8(3), 269-278.

Kusni, A., Kadir, N., \& Nayan, S. (2013). International tourism demand in Malaysia by tourists from OECD countries: A panel data econometric analysis. Procedia Economics and Finance, 7, 28-34.

Lee, C. C., \& Chang, C. P. (2008). Tourism development and economic growth: A closer look at panels. Tourism management, 29(1), 180-192.

Lise, W., \& Tol, R. S. (2000). Impact of climate on tourist demand. Climatic change, 55(4), 429449.

Mangion, M. L., Durbarry, R., \& Sinclair, M. T. (2005). Tourism competitiveness: price and quality. Tourism economics, 11(1), 45-68.

Nowak, J. J., Sahli, M., \& Sgro, P. M. (2003). Tourism, trade and domestic welfare. Pacific economic review, 8(3), 245-258.

Patsouratis, V., Frangouli, Z., \& Anastasopoulos, G. (2005). Competition in tourism among the Mediterranean countries. Applied economics, 1865-1870.

Pearce, D., \& Butler, R. (2010). Conclusions: Trends and advances in tourism research. Dalam D. Pearce, \& R. Butler, Tourism research: A 20-20 vision (hal. 229-237). London: Goodfellow.

Proença, S., \& Soukiazis, E. (2005). Demand for tourism in Portugal: A panel data approach. Coimbra, Portugal: Escola Superior Agrária, Instituto Politécnico de Coimbra.

Sakai, M. (2006). 12 Public sector investment in tourism infrastructure. International handbook on the economics of tourism.

Samimi, A. J., Sadeghi, S., \& Sadeghi, S. (2011). Tourism and economic growth in developing countries: P-VAR approach. Middle-East Journal of Scientific Research, 10(1), 28-32. 
Schubert, S., Brida, J., \& Risso, W. (2011). The impacts of international tourism demand on economic growth of small economies dependent on tourism. Tourism Management, $32(2), 377-385$.

Spurr, R. (2006). Tourism satellite accounts. International handbook on the economics of tourism, 283-300.

Utami, R., Hartono, D., \& Awirya, A. (2016). Analysis of the Competitiveness of Indonesia Tourism Price Compared to the Competitors (Demand Elasticity Approach). Jurnal Ekonomi Pembangunan: Kajian Masalah Ekonomi dan Pembangunan, 17(1), 108-124.

Weng, C. C., \& Wang, K. L. (2004). Scale and scope economies of international tourist hotels in Taiwan. Tourism Management, 25(6), 761-769. 